\title{
Entre americanos e ibéricos: teoria social na Primeira República brasileira
}

\author{
Maro Lara Martins *
}

\section{Resumo}

Neste texto, exploramos as matrizes clássicas do pensamento social e político brasileiro, o americanismo e o iberismo, associando-as aos conhecimentos sobre a sociedade, a política e a história, processando no alcance, as possibilidades e os limites teóricos do liberalismo e do federalismo da Primeira República brasileira.

Palavras-Chave: pensamento social brasileiro, teoria social, sociologia da cultura.

\section{Introdução}

$\mathrm{U}$

m dos temas clássicos das ciências sociais refere-se a uma articulação entre intelectuais, sociedade e política no andamento moderno brasileiro. Nesse cenário, polarizaram-se os estudos sobre os intelectuais em torno de duas perspectivas: uma que se atém a dimensão de uma história das ideias; outra que insiste na reconstrução estritamente sociológica do intelectual, visando à composição de uma sociologia dos intelectuais. Guardada as opções metodológicas, a primeira orientação tem como preocupação principal a análise de textos, contextualizados em função das interpretações implicadas sobre os processos sociais estudados e das configurações históricas abrangentes a partir das quais se constituiriam. Enfatizase, na segunda, a reconstrução sociológica dos meios específicos nos quais a atividade intelectual se realizaria em meio às disputas

* Mestre e Doutorando em Sociologia pelo Instituto Universitário de Pesquisas do Rio de Janeiro (IUPERJ), bolsista Capes. Endereço eletrônico: marolara@gmail.com. 
motivadas pelas possibilidades de acesso e controle das posições dominantes do campo de atividades estudado ${ }^{1}$.

De um lado, os que buscam decifrar a lógica interna dos textos e seus significados inscritos na própria tessitura da escrita como instância decisiva para a compreensão de ideias e sentidos. De outro lado, os que se propõem analisar as condições sociais de produção dos textos e a rede de vinculações que envolveriam autores, instituições e obras, decifrados em função das experiências concretas dos seus produtores.

Neste texto, optamos por uma análise a partir de uma concepção da linguagem e do texto produzido como tentativa de ordenação do mundo. Assim, os intelectuais são entendidos como um grupo social cuja ação se centra para a organização da cultura ${ }^{2}$. Esse sentido da ação social dos intelectuais está voltada para uma racionalização do mundo, a partir de um encadeamento teórico produtor de conceitos. Ideias que servem como uma espécie de norte orientador de indivíduos e de grupos sociais. Na modernidade brasileira, adquirem papéis fundamentais no artifício do mundo público, na composição dos interesses, na motivação às ações sociais, nas alterações institucionais, na organização da cultura.

Em suma, os intelectuais são os empreendedores de uma cultura política através dessa racionalização efetuada pela linguagem e por sua ação enquanto grupo social. Nesses termos, é válido dizer que os homens produzem conhecimento sobre o seu presente, interpretam o passado da sociedade em que vivem e são capazes de iluminar o futuro, e isso não de forma teleológica, mas sim de um ponto de vista político prático, mobilizador de ações sociais e estimulador de interações entre indivíduos, gerador de solidariedades tanto verticais quanto horizontais, inseridos em uma rede de interdependência. Não se trata mais de percebê-los como produtores de conceitos que somente classificam experiências, mas sim de conceitos que criam e recriam experiências e expectativas.

1 Para uma discussão mais abrangente sobre essa diferença metodológica: Miceli, 1989 e Maia (2008).

2 Não há como negar a dívida com Gramsci (2004) e, no caso específico do Brasil, com Werneck Vianna (1997). 
Experiências individuais e experiências coletivas. Expectativas individuais e expectativas coletivas ${ }^{3}$.

Em primeiro lugar, nos propomos a discutir as ideias pelas quais Alberto Sales, Sílvio Romero e Oliveira Vianna, norteavam sua posição dentro da sociedade, no sentido de definir seu papel e suas incumbências no mundo em que viviam. O que está em jogo, é a criação de uma autoimagem pela qual sua sociabilidade era estabelecida. Isto incluía os pressupostos de uma ação interventora dentro da sociedade, seja pelos referenciais cientificistas, seja pela idealização de uma civilização europeia em relação ao atraso brasileiro, seja pela experiência vivida e a recusa pela organização sócio-política instituída, seja pelos resultados obtidos por suas reflexões.

Por outro lado desta ponderação, cabe a avaliação das idealizações efetuadas por estes autores sobre o mundo em que viviam. Trata-se também da constituição de uma teoria do conhecimento. Desta forma, somos levados a cogitar o modo pelo qual o mundo em que viviam era caracterizado. Estes pontos nos levam a outro panorama reflexivo, que se refere a construção de uma tradição e de uma história que fossem genuinamente brasileiras, que incluía tanto uma concepção de tempo histórico peculiar, como a elucidação dos personagens característicos desta história. $\mathrm{O}$ aparecimento da história como fonte de conhecimento da política e da sociedade merece atenção, pois, a partir do momento em que se criou um conjunto de instrumentos intelectuais, capazes de fundamentar as opções tomadas pelos pensadores na construção de teoremas de organizações sócio-políticas, houve um processo de depuramento das possibilidades práticas justificadas através da história. $O$ ponto comum que se ressalta são as contradições e os percalços da modernidade à brasileira.

De certo, não é tarefa das mais fáceis a resposta imediata a esses questionamentos. A definição do "quem somos" e do nosso destino, estaria condicionada às idealizações sobre o passado, construindo as próprias idiossincrasias. Este processo construtivo, no Brasil, nunca se completou por inteiro. Não temos uma história

3 Sobre a percepção da experiência e da expectativa na modernidade, inspiro-me, sobretudo, em Kosseleck (2006). 
linear ou definitiva. Qualquer que fosse o caminho a ser percorrido, o passado era o ponto central de onde qualquer solução precisaria ser encontrada. Esta carga atávica apareceu sempre como ponto de partida para se construir o futuro. As linhagens teóricas, americanista e iberista, em certo sentido, fornecem argumentos importantes nessa busca por uma interpretação do caso brasileiro (WERNECK VIANNA, 1997; BRANDÃO, 2005). Os que associavam a América como modelo para o mundo moderno e os que percebiam as dificuldades de um caminho fora do eixo norte-americano/europeu-ocidental, recorriam, igualmente, ao passado para justificar os obstáculos à modernidade brasileira.

Tornaram-se clássicas as afirmações de Richard Morse (1987) sobre o espelho entre as duas Américas, as de matrizes ibéricas e americanas. $\mathrm{O}$ ponto central deste debate era a relação entre $\mathrm{O}$ privado e o público, entre o indivíduo e a comunidade, herdada pelas Américas em seu processo constitutivo colonial. No iberismo, haveria a identificação da ausência do individualismo anglo-saxônico como fator explicativo da incapacidade brasileira para se organizar a sociedade política. Haveria uma análise entre os iberistas, sobre a ausência do espírito de iniciativa, a fragilidade da consciência coletiva e a excessiva dependência do Estado, portanto, não se teria a formação da cultura material e do civismo da América anglo-saxônica. A tradição iberista salientaria os aspectos integrativos, participativos e afetivos, com ênfase na comunhão, na incorporação, na predominância do todo sobre o indivíduo. Em contraponto, a perspectiva americanista elaboraria o elogio ao individualismo, ao self-made man, ao materialismo e à política como lugar do conflito.

No plano do processo histórico concreto, com o advento da República brasileira e a Constituição de 1891, organiza-se uma caminhada rumo a certo tipo de americanismo. Um americanismo reinventado, que reposicionou os agentes no interior de uma estrutura de poder e de um novo princípio de autoridade, consagrando uma nova ordem legal, que possuía como elemento central o reconhecimento da autonomia política dos Estados, e sua consequente incorporação ao sistema federativo. Entretanto, a partir da solução imposta por Campos Sales, se manifesta a ambiguidade das novas práticas e a sobrevivência de velhos hábitos, como a forma geral dos 
conflitos, expresso na luta entre facções, na investidura da autoridade nas práticas eleitorais, e na relação público/privado, geral/particular (ANDRADE, 1981). A política dos governadores bloqueava o sistema de diferenciação política, negando as situações conflituosas do mundo público. A República brasileira nascera sem um programa efetivamente democrático (CARVALHO,1987; LESSA, 1988).

Nesta República, encarnava-se a simbiose entre a penetração dos interesses modernos, americanistas, com o patriarcalismo moral tradicional, iberista. Neste redemoinho, nesta espécie de revolução sem luta, a início estritamente política, contraditória na Carta de 1891 com sua efetividade prática, juntaram-se elementos aparentemente irreconhecíveis entre si. Tanto a América quanto a Ibéria, carregavam em si, o peso do passado e reconfigurava aquele contexto (WERNECK VIANNA, 1997).

O empreendimento teórico de Alberto Sales centrava-se na tentativa de elucidação dos meandros evolucionários que permitiriam a evolução histórica e a formação das idiossincrasias das nacionalidades. Existiam duas proposições gerais em toda sua obra postas na ação do tempo: uma proposição teórico-política, de afirmação da teoria republicana e democrática de organização estatal associada ao liberalismo, e, uma proposição teórica-social, de abordagem do mundo industrial e dos meandros sociais que permeiam a nacionalidade, como a solidariedade e a cooperação no mundo moderno.

Alberto Sales procurava o retorno às nossas raízes americanas. Em sua opinião, o desenrolar civilizatório nos trópicos, especialmente enquanto novo mundo, nova sociedade e novo homem genuinamente americanos, fora interrompido pela vinda da família real portuguesa em 1808 . Fato este, que promoveu o desajuste entre o tempo social e o tempo político. A obra da monarquia sobre esse tempo social, produtor de ineditismos, arrefeceu as características americanistas, liberais e democráticas.

Segundo Sílvio Romero, teríamos elementos ibéricos e americanos de uma forma bastante peculiar, nunca se esquecendo que em nosso teatro histórico, estava montado o palco de uma civilização que se reinventava. A tônica de sua argumentação se baseava sobretudo na formação de um novo homem e uma nova 
cultura, possibilitados pela miscigenação. Em certo sentido, Romero representa a tensão entre a concepção de América, encarnada por Alberto Sales e a Ibéria de Oliveira Vianna. Pela disputa entre essas matrizes rivais, sem que uma interpele completamente a outra, a cada momento de sua vida, admitiu elementos de ambas.

Assim como em Alberto Sales e Sílvio Romero, em Oliveira Vianna, as relações efetuadas entre a concepção de história, de política e sociedade, estão cunhadas como pressupostos para a organização do Estado. Para ele, neste território, a América seria outra, a de "baixo", caracterizada pelos atavismos da colonização. A saída estaria em retomar os projetos efetuados pelo Estado Português, e, principalmente, a concretização da obra da monarquia. $\mathrm{O}$ que predomina no fundo, como marca civilizatória são os elementos ibéricos. A República não dera conta de apagar essa fatalidade do ambiente social e político. No entanto, tal Ibéria estaria escondida, agindo subterraneamente no Brasil real. Vianna observava a inadequação da composição entre o liberalismo e o federalismo como projeto civilizatório. Sobretudo, por não serem instrumentos capazes de induzir a integridade nacional, a ordem, a legalidade e o ajustamento com a realidade social. Seriam ideias exógenas que não compartilhariam o senso de realidade que se monta a partir da constituição de um homo sociologicus desde a Colônia.

\section{Alberto Sales e a latência americanista}

Leitor de Spencer, Comte, Stuart Mill e Tocqueville, Alberto Sales ansiava a concretização da imagem que este último fizera anos antes da América. Desde a viagem de Tocqueville aos Estados Unidos, no século XIX, esse se tornou mais um paradigma de constituição social e política, cujo exemplo lastreava a humanidade: a democracia (JASMIN, 2005). Nada melhor do que estudá-la no seu caso mais específico e onde seu "espírito" mais se desenvolvia: a América, que na verdade, seria um apêndice do caso inglês. Para tanto, Tocqueville (1977) desenvolveu uma análise da sociedade americana procurando os fundamentos, as causas e o funcionamento desta democracia. Ele estabeleceu reflexões sobre os aspectos políticos, jurídicos, culturais e sociais da organização democrática norte-americana. 
A América, vista por Tocqueville, possuía um interessante ponto de partida: a unidade linguística e cultural, as origens comunais de governo e a crença na soberania do povo, se atentando para o fato de que a América teria o mesmo grau de civilização (costumes e hábitos do povo). A especificidade do caso americano se encontrava, para ele, na participação do povo no que diz respeito à coisa pública, tendo por sentido, a ação baseada no bem comum, estimulado pela dinâmica da comuna (township) e pela própria estrutura administrativa. A descentralização administrativa seria um imperativo para a liberdade. As instituições democráticas exigiriam que cada cidadão desempenhasse um papel prático no governo, moderando o seu excessivo gosto pelas teorias gerais, o americano, seria assim, um ser social pragmático.

Na América de Tocqueville, a democracia uniria o interesse particular ao interesse geral, para brecar o individualismo. As instituições sempre lembrariam ao indivíduo que ele está em sociedade. A doutrina do interesse bem compreendido seria um empreendimento filosófico e moralista, que se reforçaria através do hábito e ressaltaria a questão da utilidade das proposições na vida prática e cotidiana do indivíduo. A moral proveniente das associações uniria os homens ao redor de interesses grupais, a religião afagaria os interesses materiais na igualdade. A liberdade seria o único recurso que obrigaria os cidadãos a se basearem nos negócios comuns, na medida em que, a igualdade de condições estimularia o individualismo. A liberdade democrática gerava a procura de prazeres materiais através da indústria (WERNECK VIANNA, 1997).

Segundo Alberto Sales, seria nesta "América tocquevilleana", o modelo específico de entrada na modernidade da qual o caso brasileiro seria parte integrante. Ele apontava que "todas as aspirações, todos os sentimentos, convergem hoje para o regime da mais perfeita igualdade; e quando uma crença se enraíza no coração das massas, ela passa imediatamente da ordem social para a ordem política. De sorte que a abolição dos privilégios sociais traz como consequência inevitável a eliminação dos privilégios políticos" (SALES, 1985, p.52). O mundo do interesse público se associava à aspiração moderna da igualdade, tendo em vista a promoção do bem comum via participação política e a satisfação dos interesses sociais. 
A autonomia política, administrativa, econômica e financeira, dos Estados e Municípios criaria um novo sentido às atividades públicas, pois, indivíduo e Estado, se tornariam entidades mais próximas. Seria assim, que a Constituição e o Direito se caracterizariam como monumentos orgânicos da própria sociedade, uma vez que, deveriam consagrar "de uma maneira formal e positiva, todas as liberdades individuais e sociais e cercá-las de todas as garantias precisas para a sua efetividade real, de modo a ficarem todas completamente fora da ação do poder político" (Ibid., p.37).

Apontava neste sentido o forçoso advento de uma autoridade reguladora desta diversidade das necessidades que brotariam dos agrupamentos sociais, responsáveis também, pelo fenômeno da cooperação social. "À cada órgão a sua função e a cada função o seu órgão" (Ibid., p.22). A autonomia política dos Estados, e o consequente processo de descentralização, propiciariam o desenvolvimento moral e material da sociedade. A chamada lei do progresso em sociologia, inspirada em Spencer, montada sobre a dicotomia integração/desintegração, ou em outra chave, conservação/renovação, preconizava o papel da reconstrução da nacionalidade, ao estipular pelo federalismo, a unidade nacional.

Deste modo, estava montado o arquétipo do sistema representativo saleano. Da união entre o interesse liberal, o federalismo e a evolução social, o resulta seria o sistema representativo à americana. Tratava-se de reorganizar esta pulsão democrática, perdida com a chegada da família real ao Brasil, dentro do organismo social.

Que no sistema representativo não se reconhece parcela alguma do poder público, que não tenha a sua origem na sociedade: que a nação não deve ser privada um só instante do poder de fiscalização, por isso que ela deve, quando quiser, regular todas as funções do governo; que a autoridade governamental não é objeto de transmissão hereditária, que se adquira pelo simples fato do nascimento; que todas as funções públicas devem se achar subordinadas ao princípio eletivo, visto como poder de fiscalização suprema deve residir inteiro na nação; que os indivíduos que exercem o poder governamental devem todos ser escolhidos pela nação, em virtude do elemento eletivo ou móvel, único capaz de impedir que esse mesmo poder venha a se degenerar em uma soberania de direito 
plena e constante; e finalmente, que a mudança é tão necessária ao governo como a própria divisão dos poderes (Ibid., p.44).

A ação do sistema representativo deveria estimular o desenvolvimento dentro da ordem gerando a organicidade e funcionalidade próprias ao progresso moderno. Para Sales, a ordem social, poderia ser natural ou artificial, "conforme se o lugar que cada indivíduo ocupa no seio da sociedade é determinado imediatamente pelas suas próprias aptidões ou por uma vontade arbitrária qualquer." A ordem na democracia deveria ser engendrada pelo processo contínuo do tempo histórico, conservação/renovação. A monarquia brasileira era vista como o regime da "imobilidade e da permanência: a negação formal de todo espírito de renovação. (...) A República, ao contrário, é um governo essencialmente elástico, essencialmente liberal, essencialmente perfectível", assim, "é um governo em que a soberania popular reside inteira na nação, em que todas as atividades são cuidadosamente aproveitadas, em que as modificações se fazem com facilidade; em uma palavra, é um governo de discussão e publicidade" (Ibid., p.50).

O liberalismo de Sales o levava a crer que a participação política se daria através da organização dos interesses, criados espontaneamente pela sociedade. Assim, à "iniciativa individual é que se deve deixar entregue a livre expansão da atividade mercantil, ocupando-se apenas o Estado em favorecer, por meio da mais ampla liberdade de associação e contrato, o constante congraçamento dos esforços e dos capitais particulares" (Ibid., p.26). Neste mundo dos interesses, estava presente a noção de uma sociedade orgânica e funcional. Pela junção destes interesses individuais, fomentados pela cooperação rumo à concretização de objetivos comuns, a integração social se daria pela identidade de funções dentro do organismo social. Pelo conjunto de dependência mútua entre estas funções se criariam as condições para a integração da nacionalidade. Esta seria a mesma lógica, aplicada por Sales, em sua versão do federalismo. Pelo interesse individual, chegar-se-ia ao interesse coletivo, pelo interesse dos Estados, chegar-se-ia ao interesse nacional.

Entretanto, após o advento da República, o funcionamento prático do regime insinuara a ele os desafios de uma ampla reforma 
política e moral. Era preciso redefinir os órgãos e as funções da administração pública e da opinião, no arquétipo de organização republicana e democrática, para que o sistema adquirisse a funcionalidade necessária.

Nessa marcha civilizatória rumo a esse peculiar destino americano, haveria a necessidade de uma intervenção no tempo social. A implementação da representação, da federação e da reorganização do trabalho, como problemas que solicitavam respostas no âmbito da consolidação da nacionalidade, estariam agora, associados ao que ele denominou de concurso sistemático. Certamente, para Sales, a ideia de federação traria consigo a descentralização do poder político, a unidade nacional e o equilíbrio das forças democráticas propulsoras do interesse coletivo. Entretanto, ao apontar uma situação de metamorfoses regressivas, esse tempo político, caracterizado pela falta de senso cívico e de responsabilidade, necessitava de uma reelaboração. "Daí ainda este desprezo que em muitos países tem merecido da parte de estadistas como Bismarck, que, saltando por cima da ficção reinante, sabem compreender melhor os destinos social e político da sua nacionalidade e empreendem com rigor e energia a grande obra da integração nacional” (Ibid., p.41).

Segundo o regime representativo, que é o atualmente estabelecido entre todos os povos continuadores da civilização ocidental, com algumas modificações neste ou naquele Estado, conforma a índole e as tradições históricas de cada nacionalidade, o povo delega os seus poderes soberanos a mandatários de sua escolha, eleitos temporariamente como funcionários ou executores de sua vontade. A eleição aparece, pois neste regime como um verdadeiro artifício político, para a constituição da representação nacional, órgão autorizado da opinião. Quer isto dizer que nos governos representativos, qualquer que seja sua forma, supõese sempre que a assembleia nacional (...) é o órgão legítimo da opinião e como tal cumpre-lhe o dever primordial de ser, perante o governo ou o poder executivo, em quem se encarna a função administrativa, a intérprete fiel e sempre vigilante das necessidades mais ou menos urgentes da coletividade social. (...) Qualquer que seja a organização das assembleias, nunca aparecem os seus membros como uma corporação uniformemente constituída pelo sentimento moral do dever e do respeito aos interesses reais da nação, senão como um ajuntamento heterogêneo de grupos 
rivais, mesquinhos pelas paixões dominantes e desprezíveis pela reconhecida incompetência (SALES, 1997, p.39-40).

Dada esta situação vivida na República brasileira, a figura do publicista surgiria como fonte de resolução destes males, ao intervir no seio deste tempo social, cativando através da opinião e do debate público a democracia e corrigindo as disfunções do sistema representativo.

\section{Sílvio Romero e a tensão entre as matrizes}

Se considerarmos a obra de Sílvio Romero em conjunto, observaremos que em suas posições estavam presentes elementos de duas tradições. De início, Sílvio apontava para uma saída à americana. Entretanto, com o passar do tempo, e com a consequente desilusão republicana e ânsia pelo descobrimento do Brasil real, sua posição se afeiçoaria mais ao iberismo. Desta pulsão entre o americanismo e o iberismo em sua obra, resultará grande parte das polêmicas em que se envolveu.

Nos seus primeiros estudos sobre a literatura brasileira, Romero apontava para os fatores pelos quais a identidade nacional seria construída. O processo de colonização congregava o encontro de três raças, cada qual com sua cultura e seus modos de existência. $O$ Brasil, seria assim, um país mestiço. Neste jogo de ações e reações de uma psicologia social assim formada, composta de crenças, ideias e sentimentos, se organizaria a sociedade, base para o empreendimento da política. Entretanto, como ele assinalava:

Atravessamos uma época de crise para o pensamento nacional: na política e na literatura o momento é grave. Numa, como noutra, nos falta a força própria. Bem como na ordem social nos falha a vida do município e a dignidade do trabalho independente, assim nas letras falece-nos o peso das convicções maduras e a sublime audácia dos espíritos emancipados (ROMERO, 2002a, p.41).

A força criadora americana, associada à capacidade orgânica da literatura e seu eventual dinamismo civilizador, se construiria paulatinamente, no sentido do progresso ocidental. Como principal 
característica da evolução histórica, o "novo" no mundo, o gérmen da modernidade, no fundo, a americanidade, estariam de alguma forma latentes. Não haveria dúvida sobre a originalidade civilizatória que se estabeleceu aqui. Assim, o homem americano,

deve aceitar o fato da civilização e não querer por-se fora dela. Deve apoderar-se das novas inspirações, que ilustram a ciência atual, e procurar acompanhá-las, entrando na pugna como combatente e não como espectador. A civilização moderna é uma obra complexa; para ela todos os povos devem agitar-se. À América, cumpre não esquecê-lo, cabe trabalhar também. Então seremos originais e, ao mesmo tempo, de nossa pátria. Nessa grande obra da civilização não há privilégios de raças e continentes; há somente o privilégio da força criadora. Quem mais trabalha e adianta, mais preitos e considerações tem (ROMERO, 2002, p.66).

Apesar de tratar da América, como territorialidade de um experimento original, e ao mesmo tempo universal, de certo, a "nossa" América guardaria as influências lesivas do português, do índio e do negro. A diferença no sentido da colonização entre as Américas seria mais um elemento apontado com vistas à concretização deste destino, que unificaria o geral e o particular, a nação e o universal.

Os portugueses não vieram se fixar aqui com o mesmo espírito que os ingleses na América do Norte. A fonte da população anglo-americana foi em larga escala de puritanos. O caráter que presidiu-lhe foi bastante livre e elevado. Nossa origem embebeu-se de outras aspirações; 0 católico e o aventureiro, que para aqui vieram, prendiam suas raízes na tirania. $O$ povo inglês naquele tempo tinha sede de liberdade, as lutas religiosas estavam em seu dia. $O$ povo português dormitava na beatice; a Inquisição tinha a sua noite (ROMERO, 2002, p.63).

No embate com as velhas concepções de mundo herdadas, o americanismo sairia vencedor. Na medida em que "a nação brasileira, se tem um papel histórico a representar, só o poderá fazer quanto mais separar-se do negro africano, do selvagem tupi e do aventureiro português" (ROMERO,2002, p.104). Assim, seria que a democracia pulsaria nesses corações americanos, destruindo os atavismos de formação e de pensamento, alargando cada vez mais a distância do iberismo. "É a vida democrática e livre, o americanismo, que mata o indianismo, como mentiroso e selvático, e o lusitanismo, 
como poeirento e despótico. É a alma americana, como a civilização moderna a fortaleceu, crente no homem e não nos fantasmas do pensamento" (ROMERO, 2002, p.67). O americanismo associava-se ao moderno, à democracia, à igualdade, à liberdade, ao "materialismo" das concepções sociais, contraponto das teorias "metafísicas" de organização da autoridade social e política. O caso brasileiro seria uma dessas "nações novas", cuja nacionalidade se achava em construção. "É banal ainda repetir que a história do Brasil -literária e política- está de todo por fazer. Não há um só tipo nacional que ocupe por direito seu lugar" (ROMERO, 2002, p.76). A identidade nacional, típica deste tipo de desenvolvimento histórico, poderia articular as tradições rumo a um novo tempo social.

A literatura brasileira, a de toda a América, deve ser adiantada como filha mais nova da civilização atual; deve dar a lição de uma literatura que paira muito alto sobre os prejuízos das raças, embriagada pelo incentivo da liberdade; deve ser pensadora e democrática, séria e imperturbável, viril e fecunda; como a força de nações novas que se aparelham para representar a terceira fase da civilização: 0 mundo américo-europeu, como o chamava o filósofo. Ela não há de ser a reprodução de um passado, que já morreu, quer ele haja sido americano, quer não. À América cumpre não pedir inspirações à morte, ou ela se lhe antolhe no Velho ou no Novo Mundo. Cabelhe formar a consciência clara do seu futuro, e começar, desde já, a trabalhar para ele (ROMERO, 2002, p.68).

O americanismo estava se realizando apesar do iberismo. No ano da instauração do regime republicano publicou-se com o apoio 4 de Sílvio Romero, a Mensagem dos Homens de letras do Rio de Janeiro ao Governo provisório da República do Brasil:

O povo, e, quando dizemos o povo, referimo-nos àquela grande parte da nação que os aristocratas de todos os tempos chamaram desdenhosamente o terceiro e o quarto estado, donde, reparai bem, em sua maioria saiu sempre o nosso glorioso exército; os homens de letras, e, quando dizemos os homens de letras, referimo-nos a todos aqueles que, tomando a si os encargos intelectuais da pátria,

4 Algumas fontes apontam que foi o próprio Sílvio Romero quem redigiu este texto (MOTA,2000). 
foram, no curso de quatro séculos, os fatores mais energéticos e mais desinteressados de nosso progresso; plebe e pensadores, sempre estas duas forças caminham aqui unidas! (Apud MOTA, p.42)

Com o advento do regime republicano, houve no discurso romeriano um momento de euforia com o novo regime. Em 1894, Sílvio Romero abordou o advento da República relacionando-o a aspectos da sociedade brasileira, onde a constituição do povo deteve papel central no processo de "democratização" do país. "A república foi uma vitória dessas populações novas, representadas por seus homens mais eminentes, e por isso ela tem o apoio e reclama os aplausos de nosso povo. Ela representa a maioria e tem assim um esteio etnográfico" (ROMERO, 2001a, p.75-76).

Desta forma, a participação social era o elemento central na organização republicana, na medida em que a República estaria em consonância com os interesses da maioria. Expressaria a correspondência íntima da sociedade com a política através de um americanismo particularizado no Brasil. Neste momento de sua vida, Sílvio Romero acreditava na junção entre o federalismo e o parlamentarismo como alternativa política para o Brasil (ROMERO,1979).

Após a estruturação da ordem oligárquica na Primeira República e a decepção republicana, notamos na obra romeriana um posicionamento crítico ao federalismo e a proposição de uma República Unitária Parlamentar, com a incumbência de promover a igualdade através da democracia e da mestiçagem. Sua abordagem requereria uma concepção integrativa, dando ênfase na incorporação do Brasil real descoberto por Euclides da Cunha. Ele estava realizando uma guinada para o iberismo, ao descobrir o Brasil a partir da chave euclidiana da civilização e barbárie, em uma tecla oposta à de Sarmento. Euclides da Cunha construiu uma dualidade contrapondo o falso Brasil do litoral ao Brasil real das zonas semiáridas. De modo que, apenas o mestiço do litoral seria degenerado, sendo o outro, simplesmente um retardatário no tempo. Como conclusão teríamos que, se um Brasil está perdido, ao outro ainda se pode delegar alguma esperança civilizatória.

As "reformas pelas cimalhas" empreendidas pela República, para Romero, criariam um processo de ilusionismo, gerando o aban- 
dono das populações interioranas pela elite intelectual e política da época. Este Brasil social, o levaria a crer que a política não poderia ser mais o lócus do conflito, e sim, da comunhão nacional. Desta forma, "o povo brasileiro, pelo seu estado de cultura, por seus antecedentes étnicos e históricos, por sua educação, por seu caráter, por suas tendências, não era nem é apto para esse federalismo que coseram aos ombros"(ROMERO, 2001b, p.189). A sua concepção sociocêntrica de abordagem exaltava a predominância da coletividade sobre o indivíduo e a capacidade integrativa. $\mathrm{O}$ caso brasileiro seria

um prolongamento da civilização lusitana, um povo americano, o que importa dizer que este povo, que não exterminou o indígena, encontrado por ele nesta terra e ao qual se associou, ensinando-lhe a sua civilização, que não repeliu de si o negro, a quem comunicou os seus costumes e a sua cultura, predominou, entretanto, pelo justo e poderoso influxo da religião, do direito, da língua, da moral, da política, da indústria, das tradições, das crenças, por todos aqueles invencíveis impulsos e inapagáveis laços que movimentam almas e ajuntam homens (ROMERO, 1979, p.171).

Neste período de sua vida, Sílvio Romero apontou como tradição histórica brasileira o comunarismo, para explicar a falta de solidariedade social e a ausência de um projeto nacional estimulado pela ideia do interesse coletivo. Desde os tempos coloniais, com a fusão das três raças, o comunarismo a partir do regime patriarcal do português e do trabalho escravo, enraizou-se nos costumes populares. Contra o americanismo, o iberismo sairia vencedor.

A verdade é que nem o colono português nem os seus escravos, índios e negros, estavam preparados para os duros trabalhos da cultura americana. A emancipação rápida perturbou isso ainda mais. Com semelhante base de família e de trabalho, o regime comunário abalado ou de Estado domina de alto a baixo em toda a nação, de norte a sul, de leste a oeste. A família aqui se poderia chamar patriarcal desorganizada em os tempos coloniais (ROMERO, 1979, p.190),

Neste andamento, a solidariedade nacional só poderia ser alcançada através de uma reorganização social e política que levasse em conta este atavismo comunário de formação. Essa origem se caracterizaria pela ausência do espírito de iniciativa do 
individualismo anglo-saxônico e a precariedade das condições na formação do self made man. Pois,

sem ter agora obtido as do regime de formação particularista, a que não chegará senão ou por uma assimilação hábil de elementos provindos das raças particularistas, ou por um sistema de educação severíssima de alto a baixo. (...) As tendências comunárias dos povos que nos formaram agravaram-se consideravelmente na estrutura da nova sociedade (Ibid., p.191).

Entretanto, o sentido atribuído ao americanismo se alterou profundamente em relação às suas concepções anteriores.

A democracia moderna, comercialista, descrente, interesseira, materialista e cúpida, fá-las pela ânsia do gozo, do dinheiro, do lucro, do capital, para urdir trustes e levantar sindicatos. Será um enorme progresso na ordem material, porém pavorosa decadência na esfera moral das relações políticas dos povos (Ibid., p.217).

Para Romero, a República não aumentou a participação dentro dos centros decisórios do Estado. Haveria um aparelhamento deste Estado pelas oligarquias, corporificado no clientelismo, na intervenção do Executivo federal nos estados e nas fraudes eleitorais. Em 1910, Romero apontava que o povo não tivera participação nenhuma no processo que culminou com a instauração do regime republicano, negando suas afirmações anteriores.

A nação tinha adormecido monárquica e na bela manhã de 15 de novembro de 1889 acordou republicana. Era muito rápido para ser sério, era único em todo o mundo para não inspirar desconfianças ao observador imparcial dos fatos sociais. A bestialização, na frase gráfica do mais sincero republicano do dia, porque tinha a sinceridade da loucura, a bestialização foi geral (ROMERO, 2001, p.113).

\section{Oliveira Vianna e a latência iberista}

Acompanhando as concepções de Alberto Sales e Sílvio Romero sobre o papel e a missão do intelectual na sociedade, Oliveira Vianna se propôs a tentativa de estudar os meandros do nosso tempo social e do nosso tempo político. Como na latência ibérica de 
Romero, para ele, a nossa América seria outra, a de "baixo", caracterizada pelos atavismos da colonização. Segundo Vianna, a saída estaria em retomar os projetos efetuados pelo Estado Português, e, principalmente, a concretização da obra da monarquia. No fundo, a República como estava organizada não dera conta de apagar essa fatalidade do ambiente social e político.

Retomando as teses de Oliveira Vianna sobre a formação colonial, podemos afirmar que do meio geográfico e do latifúndio derivaram as principais características sociológicas da colonização. O poder público fragmentou-se e sua dinâmica promoveu o desamparo jurídico e político do homem comum. O clã rural apresentou-se como a unidade social agregadora, geradora da solidariedade clânica patriarcal (BRANDÃO, 2005). Nesta interpretação, ressaltavam-se os elementos da vida rural brasileira: o isolamento das suas unidades, a ausência do mercado interno entre os setores econômicos, a falta de estradas e comunicação entre as regiões e a ausência do Estado como normatividade de direitos públicos.

Cada núcleo fazendeiro seria um microcosmo social, um pequeno organismo coletivo, com aptidões cabais para uma vida isolada e autônoma. Daí essa diferença em relação às sociedades europeias. "Nestas a divisão do trabalho, especializando as atividades, forma as classes sociais interdependentes - e as une numa solidariedade estável" (VIANNA, 1956, p.155).

Estes fenômenos em questão, com suas matrizes culturais e sociodemográficas, permitiria a Oliveira Vianna, a partir de suas ferramentas conceituais, interpretar o modus operandi de certas estruturas oligárquicas de dominação. Estruturas essas que seriam incompatíveis com a constituição de uma democracia liberal.

Em síntese: o povo brasileiro só organiza aquela espécie de solidariedade, que lhe era estritamente necessária e útil: - a solidariedade do clã rural em torno do grande senhor de terra. Todas essas outras formas de solidariedade social e política - os partidos, as seitas, as corporações, os sindicatos, as associações, por um lado; por outro a comuna, a província, a Nação - são, entre nós, ou meras entidades artificiais e exógenas, ou simples aspirações doutrinárias, sem realidade efetiva na psicologia subconsciente do povo" (Ibid., p.233). 
Este tipo de solidariedade clânica, ligada ao passado histórico não parecia, aos seus olhos, destinada a desaparecer como simples consequência do desenvolvimento ou da modernização no campo político. Oliveira Vianna apontou como uma constante cultural a existência desse padrão de dominação envolto na inoperância de uma articulação espontânea de interesses dos grupos sociais com os aparatos do Estado. Assim obrigaria o Estado a interagir com esses grupos sociais através de estruturas verticais de poder, em cujo topo se encontraria o chefe do clã rural e eleitoral. $\mathrm{O}$ oposto do modelo anglo-saxão.

$\mathrm{Na}$ Inglaterra ou na América, todos os interesses sociais, que saem da esfera, aliás muito restrita, da ação do estado, são promovidos pela iniciativa privada, pondo a seu serviço a força estupenda da cooperação social. (...) Essas formas de solidariedade voluntária, de cooperação espontânea e livre, só aparecem entre nós sob a ação empolgante dos grandes entusiasmos coletivos: a frio, com a automaticidade instintiva dos anglo-saxões, não as criamos, nem as sustentamos nunca. Partidos políticos, ou ligas humanitárias, sociedades de fins morais ou clube recreativos, todas essas várias formas da solidariedade têm entre nós uma vida artificial e uma duração efêmera (Ibid., pp.156-157).

No andamento moderno brasileiro, o poder político e o poder social se organizariam piramidalmente, de modo tal, que cada chefe rural se conectaria a outro de forma a montarem uma estrutura de dominação articulada mediante o intercâmbio de "favores" recíprocos. Uma engrenagem movida pelas questões suscitadas pela pupilagem política, pela gratidão e pela amizade. Sempre se encontraria um referente em âmbito nacional, que necessitaria controlar em âmbito regional, as autonomias de certos grupos sociais e políticos, com a finalidade de facilitar o enquadramento em tempos de eleições. Teríamos então, a situação bifronte dos chefes de Estado, o conflito entre a Nação e o partido. "Os chefes de Estado, antes de passarem pelo escrutínio popular, passam pelo escrutínio dos partidos e vivem da sua solidariedade" (VIANNA, 1921, p.128). A força aglutinante dos partidos seria a posse pelo poder ou iminência desse, desencadeando aquela terrível engrenagem política que se constituiu com a República. 
Em síntese: dentre todas essas comunidades partidárias - federais, estaduais ou locais - somente aquelas que estão, de fato no poder é que possuem uma verdadeira solidariedade moral; somente nessas o instinto gregário, o espírito corporativo, o sentimento do interesse comum, da defesa comum, do perigo comum é enérgico, resistente, definido, organizado (Idem).

A atividade política, seguia Vianna, não desenvolvido a ideia de um interesse nacional, transcendente aos interesses imediatos. A prática política ao invés disso, apregoaria uma concepção meramente partidária, fragmentária, exercida e consumida estritamente dentro do pequeno círculo do grupo, do clã, da facção, do diretório local. "De modo que essa atividade, que poderia ser, exercida á americana, um fator eficaz de educação democrática, fica, entretanto, pelo seu caráter restrito e local, obscura e invisível á nação: perde, por isso mesmo, muito do seu valor e da sua eficiência” (Ibid., p.93).

A nossa educação política se fez, quase toda, sob um regime de formação extranacional do poder público.(...) São, pois, trezentos anos de ostracismo obrigatório, de ausência legal da vida pública, de incapacidade eleitoral qualificada e aceita, no correr dos quais houve tempo bastante para fixar uma tradição, forjar um caráter e definir uma psicologia do nosso indiferentismo pela organização dos poderes públicos (Ibid., p.97).

Diante desse contexto, estava montada a estrutura de valores que se apoiaria a partir da associação entre o político e o caudilho, fato que justificaria a aquisição de aliados como principal capital político e motor das ações dentro do Estado e do mundo público. Através do estudo sistemático dessa estrutura montada, poder-se-ia chegar à fórmula do "remédio" brasileiro.

Para a determinação e a definição do conceito nacional, do conceito brasileiro do governo forte o primeiro ponto a fixar é o da realidade das nossas corporações partidárias, isto é, das nossas máquinas eleitorais, e sua verdadeira significação, a sua natureza, os seus fins, as causas da sua solidariedade, as normas habituais da sua conduta. Este é o único método racional e científico para a solução do problema (Ibid., p. 124). 
Assim, Vianna realizaria a separação entre os conceitos de liberalismo e democracia, e retornava ao iberismo sob a égide do "realismo" das condições sociais e políticas que se moldaram através do processo histórico. A democracia liberal e o federalismo da Primeira República, e o seu consequente americanismo, não encontrariam ambiente favorável ao seu pleno funcionamento.

Confundimos os agentes do poder com o próprio poder; os representantes da autoridade com a própria autoridade; os órgãos do governo com o próprio governo social. Daí a substituição muito amiudada do poder resultar em desprestígio do poder; a sucessão constante da autoridade dar em consequência a fraqueza da autoridade; a mudança contínua dos órgãos do governo produzir a desordem, a descontinuidade, a instabilidade do governo e da administração pública e emprestar à vida política do país uma feição de anarquia permanente (VIANNA, 1987, p.248).

No mundo saxão, haveria a necessidade local de satisfação de interesses comuns, a preponderância do urbano, o senso de defesa coletiva geradora de solidariedade nacional, o princípio imanente da existência social, a intelectualização do Estado e a impessoalidade do poder.

Eles (os anglo-saxões) conseguiram discriminar, com perfeita lucidez, a diferença entre o poder público, como tal, e os indivíduos, que o exercem. Através dos representantes da autoridade, conseguiram ver a autoridade em si, na sua abstração. Do conceito concreto, tangível, pessoal do estado, conseguiram elevar-se a um conceito intelectual, isto é, ao conceito do estado na sua forma abstrata e impessoal (Ibid., p.247).

Dadas todas essas condições mencionadas até o momento, a alternativa far-se-ia via estatismo, que se referia à ideia de fundar através do Estado, o sentimento e a consciência da unidade nacional e de uma grande missão nacional no alto destino histórico. Seria preciso um governo centralista e forte, que resistisse aos próprios aliados.

Governo forte (excluído o lado social da sua ação) será o que, rompendo com essas praxes más de solidariedade, tenha a energia moral precisa para realizar, dentro do próprio grupo a que pertence, 
a lei jurídica e a lei moral da justiça. De modo que a sua atitude fundamental, será, não a de quem ataca adversários; mas - a de quem resiste a correligionários, entrincheirando-se no Dever e na Lei (VIANNA, 1921, p.133-134).

Dada as suas concepções sobre o tempo histórico e sua consequente correlação com o processo evolucionário desenvolvido na Europa e na América, no tempo presente, "diante dos padrões, pelos quais se modela atualmente a moderna civilização industrial, batido um povo no campo econômico, este povo está praticamente batido no campo político: a sua soberania será uma ficção a cobrir a realidade substancial de um suseranato de fato" (Ibid., p.117).

Nesta correlação entre presentes distintos, mas que se interconectariam no tema do advento da civilização moderna, a questão social deveria ser resolvida por uma interpretação à brasileira do mundo anglo-saxão. Não mais pensado sobre o viés do passado, e sim pela via do presente. Não mais ao modo americano do liberalismo e do federalismo, e sim o da solidariedade social através do corporativismo. ${ }^{5}$

pelo sindicalismo à maneira deles, de acordo com o gênio especifico da raça. Isto é, sem preocupações políticas, sem objetivos revolucionários, sem impulsos destrutivos, contido exclusivamente dentro do campo profissional e visando objetivos práticos, de melhoria das condições de vida do mundo trabalhador, pelo desenvolvimento do bem estar individual do operário e pelo desenvolvimento do espírito de cooperação e solidariedade (Idem).

\section{Considerações Finais}

A constituição das tradições do pensamento social brasileiro com suas múltiplas singularidades e com seus percalços ao longo do tempo histórico demarca a característica das interpretações sobre o

5 Sindicalismo anglo-saxão: Louis Vigoroux e Paulo Rousiers - no qual se observa "o poder transfigurador desse sindicalismo que se assenta sobre o sentimento de independência individual e sobre o espírito de iniciativa pessoal, e tão diferente do sindicalismo doutrinário, radical, dinamiteiro, subversivo, das massas proletárias da Alemanha, da França, da Itália, da Espanha” (Ibid., p.116-17). 
Brasil. As linhagens intelectuais, e o ideário que lhe dá substrato, são apropriadas e reinterpretadas sobre diversas circunstâncias. Alberto Sales procurava o retorno às nossas raízes americanas. A obra da monarquia sobre o nosso tempo social, para ele, arrefeceu as nossas características americanas, liberais e democráticas. "A ideia de independência era a única que fornecia ao sentimento popular um ponto seguro de convergência, tornando-se cada dia mais saliente, como a primeira aspiração nacional" (SALES, 1985, p.104). Entretanto, "o brado sumamente ridículo de - independência ou morte - que se levantou nos campos do Ipiranga, como um protesto solene da colônia pela sua emancipação política, não foi mais do que uma verdadeira farsa” (Ibid., p.113). Desta forma, "a constituição social, que já se achava então perfeitamente acentuada, não foi que determinou a constituição política, segundo devia ser, senão a vontade única de um príncipe aventureiro. (...) A monarquia brasileira, portanto, não teve sua origem na vontade popular" (Ibid., p.114-115).

A República e a federação trariam consigo a descentralização do poder político, a unidade nacional e o equilíbrio orgânico das forças democráticas propulsoras do interesse coletivo, gerando a organicidade e a funcionalidade necessárias para o progresso, girando a engrenagem do tempo histórico. Tratava-se de um retorno ao nosso americanismo perdido.

Sílvio Romero encarnava a dicotomia constitutiva dos intelectuais brasileiros, a floração de uma oposição metafórica entre o novo e o velho nessa jornada rumo à modernidade.

Acabamos sempre confundindo-o com o Brasil. É que ele se parece muito com as coisas brasileiras - é um tumultuar de contrastes, de esperanças e de desilusões, um misto de simplicidade e de complicação, de erros tremendos e de boa vontade de acertar. Sílvio Romero reflete, a nosso ver, a ingenuidade um tanto complicada, das nossas elites intelectuais. Por isso mesmo ele nos atrai. O que the dá grandeza é o seu infatigável esforço de compreensão do Brasil; não é a sua filosofia. (...) Sílvio é o Brasil, atropelado, errado, mas vivo (CRUZ COSTA, 1967, p.299).

Romero procurou se contrapor a seus adversários e fornecer propostas para a modernização do país. Nos diversos assuntos que 
discutiu, recorreu a uma argumentação que o colocava em oposição às facções políticas da época, empreendendo uma busca pelas alternativas que lhe parecessem viáveis. A cada mudança de posicionamento político, surgiria uma nova construção de história para o Brasil, com a alternância na participação de diversos sujeitos histórica na esfera política brasileira. A invenção de uma história para o Brasil se relacionava com a sustentação de suas ideias sobre a sociedade e sobre a política. À medida que alterava suas preferências de organização sócio-política, mudava-se o passado, o presente e o futuro do país.

Para Oliveira Vianna, tornava-se necessário avaliar o modo pelo qual se efetivaria a reestruturação do iberismo, e uma vez mais, se colocava o dilema do peculiar processo histórico do caso brasileiro, e se este seria um obstáculo ou um suporte à criação de um mundo diferente. De um lado, se imputava ao peso da herança ibérica as eventuais dificuldades com que se defrontava o americanismo republicano. De outro lado, se procurava certa utilidade no estudo da realidade brasileira atribuindo uma valoração positiva a esse mesmo passado. Esta carga atávica apareceu sempre como ponto de partida para se construir o presente.

Dentro dessa lógica, essa inversão do tempo social teria de ser considerada dentro da historicidade do passado, e a definição de uma ontologia social deveria ser entendida dentro desta contingência propiciada pela historicidade. Resgatar o valor dessa tese do "quem somos" e sairmos em construção da superação através da antítese, e assim, sermos "outros". A necessidade, do que Oliveira Vianna chamou de idealismo orgânico, estava em definir a nossa modernidade como um lugar existente, possível, inadiável e peculiar.

Estariam definidos assim, os limites do liberalismo e do federalismo na Primeira República Brasileira. A efervescência da década de 20, no Brasil, completaria o movimento do retorno do iberismo frente ao americanismo sob a crítica ao funcionamento prático observado por nossos autores do tempo político e principalmente do tempo social gerados nessa República, levando a outros moldes dentro do republicanismo, essa convivência matricial. 


\section{Referências}

ALONSO, A. Ideias em movimento: a geração de 1871 na crise do Brasil-Império. Rio de Janeiro: Paz e Terra, 2002.

ANDRADE, R. Ordem Política e Conflito na Constituição do Estado Brasileiro: 1889-1937. São Paulo, tese de doutoramento FFLCH USP, 1981.

BRANDÃO, G. "Linhagens do Pensamento Político Brasileiro.” DADOS - Revista de Ciências Sociais, Rio de Janeiro, Vol. 48, no 2, 2005.

- Oliveira Vianna - Populações Meridionais do Brasil. In: DANTAS MOTA, L. (Org.). Introdução ao Brasil - Um Banquete no Trópico. São Paulo, 2001.

CANDIDO, A. O Método Crítico de Sílvio Romero. São Paulo: Edusp, 1988 (1945).

CARVALHO, J.M. A Formação das Almas. São Paulo: Companhia das Letras, 1990.

. Os Bestializados: O Rio de Janeiro e a República que não foi. São Paulo: Companhia das Letras, 1987.

. O teatro das sombras: a política imperial. São Paulo: Vértice; Rio, Iuperj, 1988.

CARVALHO, M.A. O Quinto Século. Rio de Janeiro, Editora Revan, IUPERJ-UCAM, 1998

HOLANDA, S.B. Raízes do Brasil. Rio de Janeiro: José Olympio, 1990.

JANOTTI, M.L.M. Os subversivos da República. São Paulo: Brasiliense, 1986.

JASMIN, M. Aléxis de Tocqueville: a historiografia como ciência da política. 2a ed. Belo Horizonte, Editora UFMG, Iuperj, 2005.

LESSA, R. A invenção republicana. Campos Sales, as bases e a decadência da Primeira República brasileira. São Paulo, Vértice; Rio de Janeiro, Iuperj, 1988.

LEITE, B. O Senado nos anos finais do Império 1870-1889. Brasília: Senado Federal/Ed. Unb, 1978.

LEITE, D.M. O Caráter Nacional Brasileiro. História de uma ideologia. 2a ed. São Paulo: Livraria Pioneira Editora, 1969. 
MORAES FILHO, E. Medo à Utopia: O pensamento social de Tobias Barreto e Sílvio Romero. Rio de Janeiro: Nova Fronteira; Brasília INL, 1985.

MORSE, R. O Espelho de Próspero. Cultura e Ideias nas Américas. São Paulo, Cia das Letras, 1987.

MOTA, M.A.R. Sílvio Romero: dilemas e combates no Brasil da virada do século XX. Rio de Janeiro: Editora FGV, 2000.

NAXARA, M.R.C. Estrangeiro em sua própria terra. Representações do brasileiro 1870-1920. São Paulo: Annablume, 1998.

NOGUEIRA, M.A. As Desventuras do Liberalismo, Joaquim Nabuco, a Monarquia e a República. Rio de Janeiro: Paz \& Terra, 1984.

NOVONTN, H. Le temps à soi: genèse et structuration d'un sentiment du temps. Paris: Ed. de la Maison des Sciences de L'homme, 1992

OLIVEIRA, L.L. A Questão Nacional na Primeira República. São Paulo: Brasiliense, 1990.

ORTIZ, R. Cultura brasileira e Identidade Nacional. 5 ed. São Paulo: Brasiliense, 2003 (1985).

PAIM, A. Historia das ideias filosóficas no Brasil. São Paulo: Grijalbo, 1967.

POCOCK, J.G.A. Linguagens do Ideário Político. São Paulo: Edusp, 2003

QUEIROZ, S.R.R. Os radicais da República. São Paulo: Brasiliense, 1986.

ROMERO, S. A Bancarrota do Regime Federativo no Brasil. Porto: Typ. Arthur José de Souza \& Irmão, Suce., 1912.

. Introdução a Doutrina Contra Doutrina. São Paulo: Companhia das Letras, 2001.

. Literatura, História e Crítica. Luiz Antonio Barreto (Org). Rio de Janeiro: Imago, Aracaju: UFS, 2002.

. O Brasil social e Outros Estudos Sociológicos. Brasília: Senado Federal, Conselho Editorial, 2001.

. Realidade e Ilusões no Brasil. Parlamentarismo e presidencialismo e outros ensaios. Seleção e coordenação de Hildon Rocha. Petrópolis: Vozes, 1979. 
SALES, A. Catecismo Republicano. São Paulo, Leroy King Bookwalter, 1885 1997. [1891]

. Ciência Política. Ed. Fac-símile. Brasília, Senado federal, . A Pátria Paulista. Brasília, Ed Unb, 1983 [1887].

SCHWARCZ, L.M. O Espetáculo das Raças: Cientistas, Instituições e questão racial no Brasil. !870 - 1930. São Paulo: Cia das Letras, 1993.

SCHWARTZ, R. Ao vencedor as batatas. São Paulo: Duas Cidades, 1977.

SEVCENKO, N. (Org). História da Vida Privada no Brasil. Volume 2. São Paulo, Companhia das Letras, 1999.

. Literatura como Missão: Tensões sociais e criação cultural na Primeira República. 4ed. São Paulo: Brasiliense, 1999.

SKINNER, Q. As fundações do pensamento político moderno. São Paulo: Companhia das Letras, 1996.

. Maquiavel. São Paulo: Brasiliense, 1988.

SKIDMORE, T.E. Preto no Branco: raça e nacionalidade no pensamento brasileiro. trad. Raul de Sá Barbosa. Rio de Janeiro: Paz e Terra, 1976.

SODRÉ, N.W. A Ideologia do Colonialismo. 2 ed. Rio de Janeiro: Civilização Brasileira, 1965.

SUE, R. Temps et Ordre Social. Paris: P.U.F., 1994

TOCQUEVILLE, A. A democracia na América. Belo Horizonte/São Paulo, Itatiaia/Edusp, 1977.

VENTURA, R. Estilo Tropical. História Cultural e polêmicas literárias no Brasil. São Paulo: Companhia das Letras, 1991.

VIANNA, F.O. Evolução do povo brasileiro. 4a ed. Rio de Janeiro, José Olympio, 1956.

. O Ocaso do Império. 4a edição. Recife, Fundaj, Editora Massangana, 1990.

. Pequenos Estudos de Psicologia Social. São Paulo: Revista do Brasil, 1921. 
. Populações Meridionais do Brasil. Volume I - Populações do Centro-Sul. 7ạ edição. Belo Horizonte: Itatiaia; Niterói: Universidade Federal Fluminense, 1987.

WERNECK VIANNA, L. A Revolução Passiva: iberismo e americanismo no Brasil. Rio de Janeiro, Editora Revan/IUPERJ, 1997.

\section{Abstract}

Between Americanism and Iberianism: social theory in the First Brazilian Republic.

In this text, we explore the classical matrixes of Brazilian social and political thought, Americanism and Iberianism, associating them with knowledge of society, politics and history, and relating them to the scope, possibilities and limits of theoretical liberalism and federalism in the First Brazilian Republic.

Keywords: Brazilian social thought, social theory, sociology of culture. 
